\title{
Synergia w ekonomii, jako czynnik miastotwórczy w Chinach
}

\author{
Dariusz Gawel \\ Samodzielna Pracownia Architektoniczna, Wydział Budownictwa i Architektury, \\ Politechnika Lubelska, e-mail: d.gawel@pollub.pl
}

Streszczenie: Artykuł odnosi się do zjawisk przestrzennych i architektonicznych dokonujących się na naszych oczach w Kraju Środka. Imponujące tempo rozwoju nie tylko w skali azjatyckiej, ale ogólnoświatowej wymusza lokowanie nadwyżek kapitałowych w nieruchomościach. Na niespotykaną gdzie indziej salę powstają nowe osiedla, dzielnice, czasami nawet całe miasta. Wraz z tworzeniem nowej architektury oraz zabudowaniem nowych przestrzeni, nasuwa się pytanie o jakość tworzonego środowiska zbudowanego w tym kraju. Jednocześnie gwałtowny rozwój ekonomiczny, pociąga za sobą nowe zjawiska społeczne dotąd nieznane w tym kraju (gwałtowna migracja ludności do miast, rozluźnienie polityki jednego dziecka czy tworzenie się nowej klasy średniej w społeczeństwie). Proces urbanizacji kraju przybiera szybko na sile, jednak plany kolejnych rządów tego kraju są jeszcze bardziej daleko idące. W artykule autor dokonuje próby analizy zjawisk architektoniczno - przestrzennych wpływających na społeczeństwo, w warunkach szybkiego wzrostu gospodarczego. Synergia ekonomiczna jest w tym przypadku przyczynkiem do zobrazowania warunków kreowania środowiska zbudowanego miast. Jak w społeczeństwie chińskim, w którym tradycja, wierzenia i rodzina są fundamentalnymi zasadami życia, można kształtować środowisko zamieszkania wg zasad wolnego rynku? Autor dokonuje tutaj analizy zjawisk na podstawie krytyki literatury przedmiotowej oraz własnych obserwacji dokonanych, ,in situ”.

Słowa kluczowe: synergia w ekonomii, element miastotwórczy, miasto, Chiny.

\section{Wstęp - ekonomiczne podstawy synergii w Chinach}

Przyzwyczailiśmy się do wieloletniego wzrostu ekonomicznego Chin. Nawet w czasach kryzysu gospodarczego w USA i Europie wskaźniki makroekonomiczne pozwalały sądzić, iż kraj ten podąża stabilną ścieżką progresu ekonomicznego. Optymizm podyktowany był poziomem wzrostu gospodarczego, nieporównywalnym do żadnego z krajów. Chiny odnotowywały wzrost we wszystkich dziedzinach gospodarki, w eksporcie i imporcie. Swoje nadwyżki ekonomiczne Państwo Środka lokowało w rozwój przemysłu, ale również w infrastrukturę techniczną, badania i naukę czy rolnictwo. Specyfika skali rozwoju gospodarczego to pewnego rodzaju synergia ${ }^{1}$. Zjawisko synergii przy ogromnej ilości drobnych kooperujących podmiotów gospodarczych, mogło jedynie zwielokrotnić pozytywne efekty pracy. Wydaje się, że efekt osiągnięcia sukcesu tego kraju, polegał na ustawicznym, czasami mozolnym wysiłku milionów Chińczyków. Fakt, iż kapitał był lokowa-

\footnotetext{
${ }^{1}$ „Integracja działań wielu podmiotów kreujących produkt zmniejsza koszty jego przygotowania i promocji, a zwiększa szanse rynkowego zakresu (czyli zyski). Efekty są nieproporcjonalnie większe w porównaniu z sytuacją, gdy każdy z podmiotów działa oddzielnie. W biznesie mamy do czynienia z synergią, gdy kilka firm lub grup pracuje razem i osiąga większy sukces niż pracując osobno. "źródło : wikipedia.pl
} 
ny w tym kraju, wynikał z jego ówczesnego poziomu rozwoju. Dziś mamy do czynienia z zupełnie odmienionym krajem. Widać to na ulicach miast, w metrze, szkołach i na uczelniach. Transformacja ustrojowa $\mathrm{z}$ jaką mamy do czynienia w tym kraju, jest ewenementem na skalę dotąd niespotykaną w historii. Przekształcenia strukturalne pozwoliły na gwałtowne przemiany społeczne, odbijające się na środowisku mieszkaniowym. Jednak nadal możemy mówić o dysproporcjach w poziomie życia na wsi i w miastach. Częściowo jest to wynikiem specyfiki tego kraju, jego wielkości i uwarunkowań geopolitycznych jakie pełniło w historii. Od ośmiu lat, jak wynika z analizy ekonomicznej, Chiny odnotowują spadki w zakresie wytwarzanego produktu narodowego, jednak nadal pozostają potęga ekonomiczną, a stworzona infrastruktura społeczna i techniczna, na długo będzie służyć jego mieszkańcom.

\section{Specyfika sieci osadniczej w Chinach}

Opisując sieć osadniczą w Kraju Środka należy pamiętać o skali i specyfice ukształtowania powierzchniowego. Tereny o największym zaludnieniu to wschód i południowy wschód. Znaczną część zajmują tereny górskie, słabo zasiedlone. Ludność zamieszkująca miasta stanowi ponad połowę ich mieszkańców.

Specyficzny podział administracyjny na 22 prowincje i 5 regionów autonomicznych. W swojej strukturze Chiny posiadają również 4 duże miasta wydzielone. O skali kraju w warunkach azjatyckich niech świadczy fakt, iż grupa 30 największych miast obejmuje ośrodki od 20 (Szanghaj) do $3 \mathrm{mln}$ (Shijiazhuang) mieszkańców. Specyfiką sieci osadniczej, najbardziej zaludnionej części Chin (wschód) jest tworzenie ścisłych związków przestrzennych pomiędzy wielkimi miastami. Osiągano to poprzez tworzenie sieci powiązań komunikacyjnych i przemysłowych. Kraj posiada doskonale rozwinięty system dróg kołowych i kolejowych, w tym szybkiej kolei, łączącej głównie najważniejsze miasta na wschodzie - od Kantonu (Guangzhou), poprzez Szanghaj, aż do Pekinu. Ale również regiony górskie dotąd niedostępne, jak Tybet zostały skomunikowane dzięki odważnym projektom infrastrukturalnym. Dopełnieniem całości jest infrastruktura transportu lotniczego, z gęstą siecią lotnisk lokalnych i międzynarodowym. Zważywszy na ilość mieszkańców Państwa Środka (1370 mln) zaczynamy rozumieć znaczenie tego kraju, w ujęciu ogólnoświatowym.

W ciągu ostatniego ćwierćwiecza migracja ludności wiejskiej do miast wyniosła około połowę ich obecnych mieszkańców, czyli ponad 300 milionów. Sprawia to, że miasta chińskie staja się coraz większe. Planowane super miasto dla $130 \mathrm{mln}$ ludności, ma połączyć stolicę kraju Pekin z nadmorskim Tianjin i całą prowincję Hebei. [1]

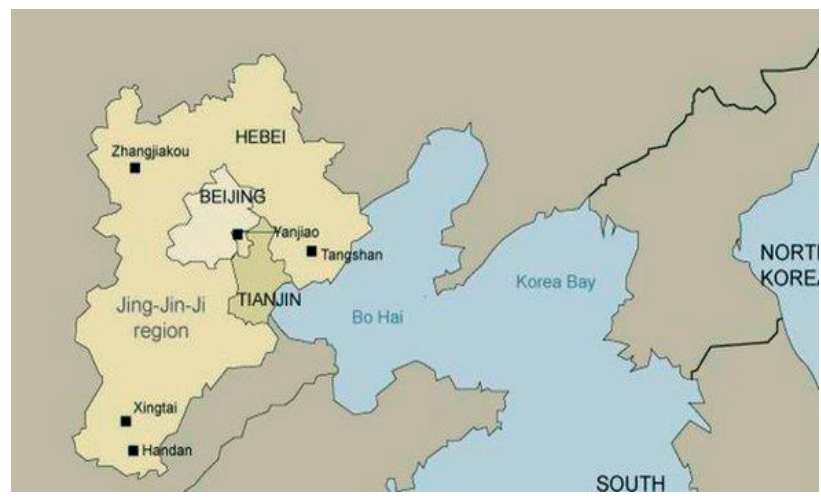

Rys. 1. Skala i zasięg terytorialny planowanego super-miasta Jing - Jin - Ji (Źródło: [1]) 
Tabela 1. Charakterystyka (funkcja i populacja) ośrodków super- miasta Jing - Jin - Ji

\begin{tabular}{|c|c|c|c|c|}
\hline L.P. & Miasto & Charakterystyka ośrodka & $\begin{array}{l}\text { Populacja, } \\
\text { tys. }\end{array}$ & $\begin{array}{c}\text { Populacja } \\
\text { - prefektura tys. }\end{array}$ \\
\hline 1 & Baoding & handlowo-przemysłowy & 1141 & 10501 \\
\hline 2 & Cangzhou & przemysłowy & 605 & 6591 \\
\hline 3 & Chengde & uzdrowiskowo-turystyczny & 465 & 3534 \\
\hline 4 & Handan & przemysłowy & 1385 & 8210 \\
\hline 5 & Hengshui & przemysłowy & 491 & 4150 \\
\hline 6 & Langfang & $\begin{array}{l}\text { przemysłowy - pomiędzy } \\
2 \text { miastami wydzielonymi }\end{array}$ & 734 & 3748 \\
\hline 7 & Qinhuangdao & przemysłowo-portowy & 833 & 2644 \\
\hline 8 & Shijiazhuang & administracyjno-przemysłowy & 2770 & 8754 \\
\hline 9 & Tangshan & przemysłowo-wydobywczy & 1628 & 11022 \\
\hline 10 & Xingtai & przemysłowy & 749 & 6512 \\
\hline 11 & Zhanjiakou & przemysłowy & 857 & 4437 \\
\hline 12 & Beijing & administracyjny - stolica kraju & 16447 & - \\
\hline 13 & Tianjin & miasto wydzielone & 9290 & - \\
\hline
\end{tabular}

Nie jest to odosobniony przypadek, podobne plany dotyczą południowej metropolii Chin Kanton (Guangzhou), nad Rzeka Perłową. Tutaj z kolei planuje się stworzenie ogromnego korytarza dla 42 milionów mieszkańców, z połączenia 9 sąsiednich miast. [2] Działania te mają na celu, w szybkim czasie podniesienie wskaźnika urbanizacji do poziomu około 60\% (zapisy Planu Urbanizacji Kraju Nowego Typu na lata 2014-2020) - obecnie wskaźnik ten wynosi 54\% [3]

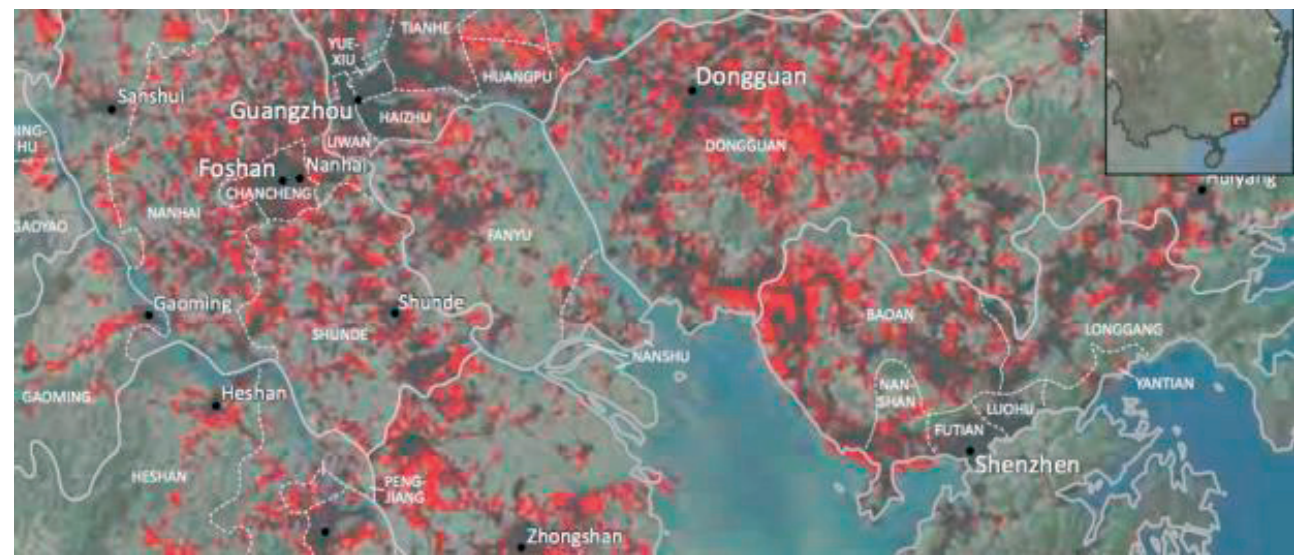

Fot. 1. Proces urbanizacji miast w delcie rzeki Perłowej. (Źródło: University of Wisconsin-Madison, poz.). Legenda: kolor brązowy - tereny miejskie w 2000 r., czerwony - nowe tereny miejskie w 2010 roku.

\section{Ksztaltowanie środowiska zamieszkania w miastach chińskich}

Szybko zmieniające się warunki podnoszenia poziomu życia mieszkańców, mają swoje odbicie w kształtowanym wg zasad ekonomicznych środowisku zamieszkania. Ludzie płacą często ogromną cenę za szaleńczy rozwój gospodarczy. Przejawia się to najczęściej w braku odpowiednich warunków życia obywateli, poprzez: 
- zanieczyszczenie powietrza, czyli tworzenie się tzw. smogu,

- zanieczyszczenie wody dostarczanej do gospodarstw domowych,

- brak należytej segregacji odpadów i zatrucie gleby.

Industrializacja spowodowała ogromny wzrost zanieczyszczenia i pogorszenie się jakości powietrza (dopuszczalna norma europejska mówi o poziomie 10 mikrogramów na metr sześcienny PM 10), co skutkuje chorobami alergicznymi wśród dzieci i kłopotami z oddychaniem u ludzi starszych (w konsekwencji staje się przyczyną wielu chorób). Miasta chińskie należą do najbardziej zapylonych w świecie, obok indyjskich, indonezyjskich czy pakistańskich. Nie dziwi już powszechne używanie masek na twarz, chroniących drogi oddechowe. W dni wolne od pracy przy widocznym zapyleniu powietrza (brak jego przejrzystości i tworzenie się mgły) wielu ludzi nie decyduje się na opuszczanie swoich mieszkań. Ostatnio dzieje się tak coraz częściej.

Woda w sieciach wodociągowych również pozostawia wiele do życzenia, Nie chodzi tutaj tylko w wartości smakowe, chociaż są one bardzo istotne, ale przede wszystkim o zanieczyszczenie jej innymi substancjami. W wielu rejonach kraju po przypadkach zgonów ludzi spowodowanych zatruciem metalami ciężkimi, bardziej zasobni zaczęli montować w kuchniach wyparzarki do naczyń, próbując w wysokiej temperaturze pozbyć się trujących związków. [4] Ale woda taka przenika i zatruwa także poprzez skórę.

Przez wiele lat gospodarki komunistycznej świadomość społeczna ochrony środowiska i usuwania odpadów była na niskim poziomie i zupełnie niekontrolowana. Do ziemi przedostawało się wiele związków i substancji trujących. Przy kolejnych inwestycjach, dochodzi do odkrywania miejsc gromadzenia tych trujących i dzikich wysypisk odpadów.

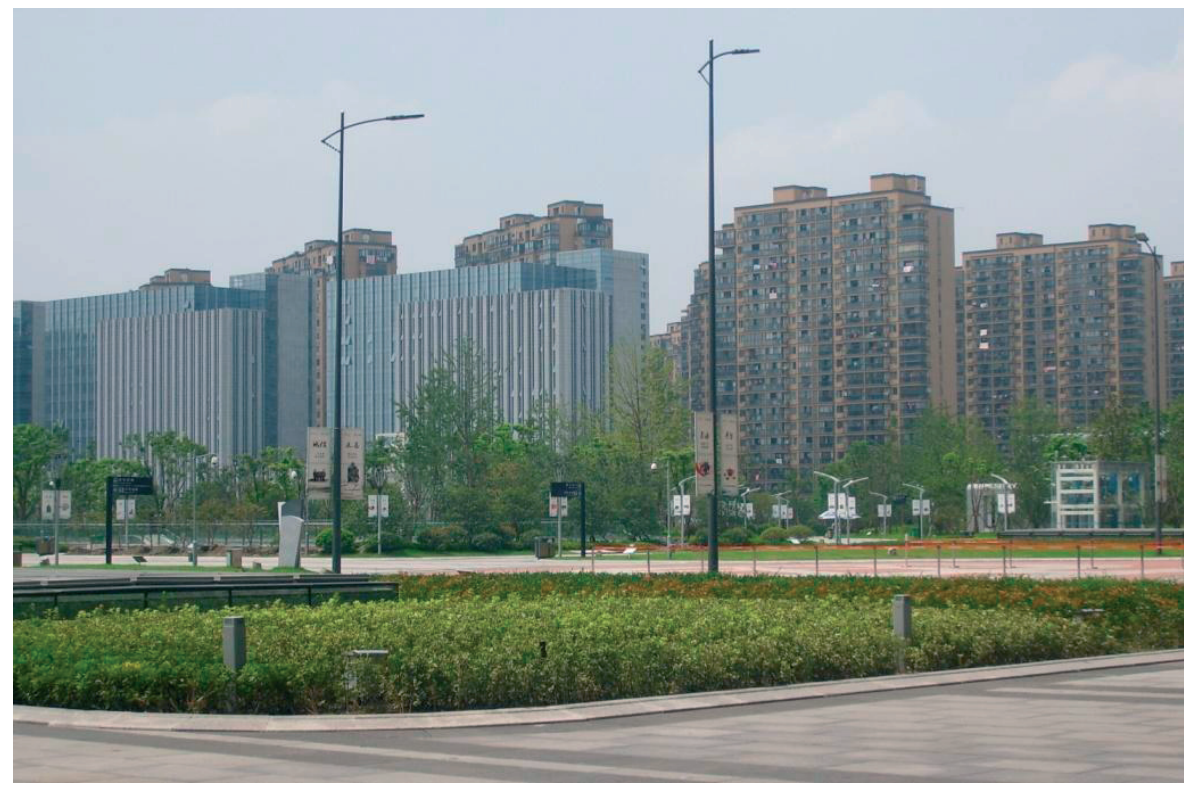

Fot. 2. Ogromne dzielnice mieszkaniowe na obrzeżach Hangzhou (prowincja Zhejiang) są typowym zjawiskiem rozlewania się miast. (Źródło : autor 2014)

Chińczycy pracują długo, często ponad wymagane 8 godzin na dobę, ale również mają świadomość konieczności podnoszenia swojego poziomu zdrowotności. W sąsiedztwie domów powstają siłownie na wolnym powietrzu i ścieżki zdrowia (w Polsce dawno zapomniane). Samodyscyplina wewnętrzna ludzi gromadzi ich (często są to ludzie starsi) 
w godzinach rannych na placach, w parkach i na skwerach w celu uprawiania tai chi (rodzaj medytacji poprzez ruch i gimnastykę) czy też zwykłych ćwiczeń przy muzyce. Kompozycja i umiejętne połączenie, jakże różnych funkcji zorganizowanej przestrzeni publicznej miejskiej daje szansę wypoczynku i regeneracji sił. Chińskie kształtowanie założeń ogrodowych i parkowych w miastach można traktować w kategoriach sztuki, opartej na wielowiekowej tradycji. [5]

Istotnym elementem środowiska zamieszkania pozostaje środowisko zbudowane. Warunki mieszkaniowe ludności chińskiej są zróżnicowane. $Z$ jednej strony powstają nowe obiekty z dużymi mieszkaniami, (w granicach 70-100 $\mathrm{m}^{2}$ ) z drugiej strony bez remontów pozostają istniejące dzielnice ze starą wyeksploatowaną zabudową i małymi przeludnionymi lokalami do $40 \mathrm{~m}^{2}$. Wznoszone konstrukcje budynków opierają się na wykorzystaniu układów szkieletowych, pozwalających na pewną dowolność stosowania obudowy zewnętrznej ścian oraz sztywne układy monolityczne. Dopełnieniem tych wysokich budynków tworzących zespoły mieszkaniowe, pozostaje dobrze skomponowana zieleń, w postaci zróżnicowanych drzew i krzewów wzbogaconych często o małe zbiorniki wodne. Do tej pory ludność nie mogła posiadać na własność nieruchomości. Dzisiaj za wysoką cenę można zakupić mieszkania, żywiołowo powstające w nowych osiedlach na dalekich obrzeżach wielkich miast. [6] Czasami są to nawet formy niskiej intensywnej zabudowy mieszkaniowej. Młody rynek deweloperów mieszkaniowych przeżywa swój największy rozkwit. Nadwyżki finansowe powstałe z rozwoju gospodarczego i oszczędności ludzi chętnie lokowane są w nowe nieruchomości. W ten sposób szybko zmienia się oblicze całych miast. Obok starych powstają nowoczesne przeszklone obiekty świadczące również o zmianie upodobań Chińczyków.

Kreowane przestrzenie centrów miast chińskich mogą porażać swoją skalą (w końcu tworzone są dla wielkich mas ludzi) jednak ich monofunkcyjność i brak odpowiedniego poziomu organizacji, sprowadza je do miejsc wyobcowanych, pozbawionych życia. Tak dzieje się w dzielnicy Pudong w Szanghaju, czy w Zhujiang New Town w Guangzhou ${ }^{2}$. [8] W wykreowanej rzeczywistości szkła i stali, człowiek ma prawo czuć się obco.

\section{Kreacja nowej urbanistyki w strukturze miejskiej}

Miasta chińskie powstają w sposób szybki, można powiedzieć żywiołowy. Czynnikami wpływającymi na to zjawisko są: tworzenie nowej klasy średniej, migracje wewnętrzne ludności ze wsi do miast oraz wzrost zamożności obywateli co przekłada się na postępującą konsumpcję towarów. Istotnym znaczeniem dla przekształceń przestrzennych w skali kraju, jest akceptacja władz na kreowanie agresywnej gospodarki przestrzennej. Skala zjawiska ekspansji miast chińskich jest ogromna. Ważnym momentem w eskalacji tego zjawiska, było przejście od rozlewającego się miasta do miasta wertykalnego (od lat 90 poprzedniego wieku do dzisiaj). Powstało wiele jeszcze wyższych budynków, w tym mieszkalnych. [7] Chodziło o maksymalne zwiększenie gęstości zaludnienia terenów zurbanizowanych. Jednak miasto wertykalne, to nie tylko coraz wyższe budynki (dające większe możliwości, przy odpowiednim poziomie techniki), ale również organizacja życia mieszkańców czy kompozycja urbanistyczna zabudowy, szczególnie strefy obrzeżnej.

\footnotetext{
${ }^{2}$, ,Kwartały zabudowy mieszkaniowej zlokalizowane na obrzeżach głównego założenia (Zhujiang New Town w Guangzhou) przeważnie mają funkcje osiedli zamkniętych. Tym samym nie wchodzą w żadne relacje z przestrzenia publiczną. Ten brak wzajemnych relacji na zmiany warunków przestrzeni sprawia, że mamy do czynienia z jednorodną przestrzenią, która rozszerza się we wszystkich kierunkach, nie zmieniając swych zależnych od funkcji własności." s. 98 [8]
} 


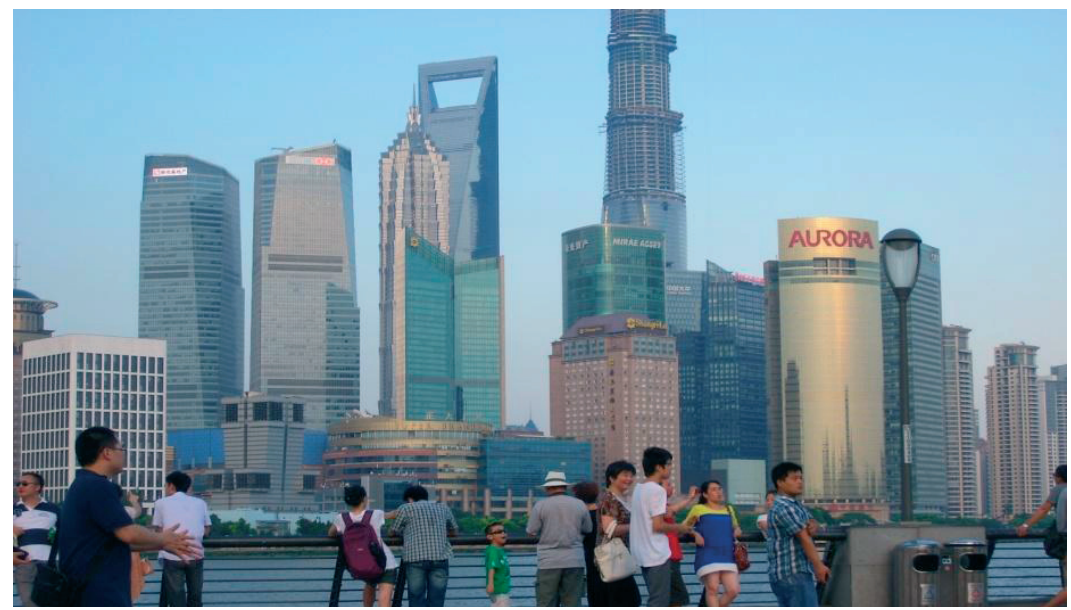

Fot. 3. Widok na dzielnicę Pudong - nowoczesne centrum handlowo- usługowe składające się przede wszystkim z wysokościowców, w centrum Szanghaju. (Źródło: autor 2013)

Czynniki miastotwórcze w przypadku Chin stają się tylko pochodną wzrostu gospodarczego. Przechodzenie od potrzeb człowieka, do odpowiedniego poziomu kreacji przestrzeni, powinno odbywać się $\mathrm{w}$ dialogu $\mathrm{z}$ nim samym. Jednak tworzenie przestrzeni miejskiej w kategoriach dobrze zorganizowanej przestrzeni publicznej środowiska zbudowanego wymaga wielu różnorodnych działań, których najczęściej nie można dostrzec ${ }^{3}$.

\section{Podsumowanie}

Zjawiska przestrzenne w Państwie Środka z jakimi mamy obecnie do czynienia, niewątpliwie są wynikiem wieloletniego wzrostu gospodarczego w tym kraju. Postępująca urbanizacja wymaga stworzenia odpowiednich warunków dla przemieszczających się milionów ludzi zasilających przemysł. Jednocześnie te znakomite wyniki gospodarcze przełożyły się znacząco na poziom życia samych mieszkańców. Pomimo tego istnieje poważna obawa o kreowane środowisko zbudowane i tworzone środowisko mieszkaniowe ludzi.

- Szybkie tempo budowania osiedli i zespołów mieszkaniowych wpływa negatywnie na monotonię i powtarzalność rozwiązań tworzonych elementów kompozycji urbanistycznych (budynki, układy przestrzenne zabudowy, rodzaje wnętrz, detal architektoniczny i urbanistyczny). Podstawowymi elementami tworzonych mieszkaniowych kompozycji osiedli (około 90\%) są budynki wysokie i wysokościowe, pozwalające na maksymalne wykorzystanie terenu inwestycji.

- Nie można stwierdzić w kreowanych zespołach mieszkaniowych, pozbawienia ich podstawowych elementów otoczenia mieszkaniowego, jednak w większości ograniczają się one do obiektów rekreacyjnych i wypoczynkowych, w bezpośrednim sąsiedztwie(tereny zieleni urządzonej, woda, infrastruktura techniczna).

\footnotetext{
„Jeśli miasto przestaje być terenem dialogu, wtedy pozostaje już tylko technika, która pozwala wznosić coraz wyższe i lżejsze wieżowce, tworzyć zawieszone w powietrzu bryły, przekrywać coraz większe rozpiętości, transportować i obsługiwać coraz większe masy ludzi. Tyle ze jest to wyścig, a nie tworzenie miasta dla człowieka." Janowski M. Totalitarna wolność, nowy krajobraz miejski na przykładzie Zhujiang New Town [w:] Nowoczesność w architekturze. Urbanistyka i architektura miasta postindustrialnego. Wydział Architektury Politechniki Śląskiej, Gliwice 2011. s.100 [8]
} 
- Zabudowa mieszkaniowa intensywnie powstająca w obrębie strefy obrzeżnej, znacząco wpływa na niekontrolowany rozrost miast (zjawiska rozlewania się miast ang. urban sprawl, są przykładami wręcz wzorcowymi).

- Gwałtowny rozwój gospodarczy i brak konsekwentnej polityki państwa w zakresie edukacji ekologicznej skutkują zanieczyszczeniem powietrza, gleby i wody, co w konsekwencji znacząco wpływa na pogorszenie warunków zdrowotności w środowisku zamieszkania.

- Zjawiska tworzenia nowych megalopolis ${ }^{4}$ jako supermiast, obniżają warunki życia ludzi w zakresie poziomu i czynników organizacji środowiska zamieszkania (np. poprzez dostęp do środków transportu publicznego, możliwość zaopatrywania się w świeże towary na tradycyjnych bazarach, ograniczenie czasu przebywania $\mathrm{w}$ domu do minimum np. spania, czy pogarszania warunków zdrowotności środowiska.

- Zjawiska powstawania nienaturalnie dużych ośrodków miejskich nie byłyby tak szybko możliwe, gdyby nie swoiste połączenie zasad ustroju państwa ludowego (opartego o gospodarkę planistyczną - z założeniami planów rozwojowych - najczęściej 5 letnich), z elementami neokapitalizmu (impulsywnego stworzenia warunków wolnego rynku, opartego na podaży i popycie na towary i usługi).

Wartość dodana (synergia) cudu gospodarczego ekonomii chińskiej, odzwierciedlona w szybkim rozwój przestrzennym kraju, może przybierać niepokojące formy. Najwyższe budynki nie przekładają się często na poprawę jakości środowiska zbudowanego tworzonych miast. Niepokojące symptomy tworzenia nienaturalnych form ogromnych zespołów osadniczych - supermiast, mogą tylko pogorszyć poziom życia mieszkańców. Wydaje się, iż jedyną sensowna formą poszukiwania kierunków dla przyszłości rozwoju terytorialnego Chin, pozostaje dialog społeczny i dobrze zrozumiana partycypacja mieszkańców.

Tabela 2. Procentowy wzrost populacji największych chińskich miast w przedziale czasowym 30 lat.

\begin{tabular}{lllcccc}
\hline L.P. & Miasto & Prowincja & $\begin{array}{c}\text { L. ludności } \\
\text { w } 1990 \mathrm{r} . \\
\text { w tysiącach }\end{array}$ & $\begin{array}{c}\text { L. ludności } \\
\text { w 2000 r. } \\
\text { w tysiącach }\end{array}$ & $\begin{array}{c}\text { L. ludności } \\
\text { w 2010 r. } \\
\text { w tysiącach }\end{array}$ & $\begin{array}{c}\text { Wzrost w ciągu } \\
\text { ostatnich } 10 \text { lat } \\
\text { w\% }\end{array}$ \\
\hline 1 & Shanghai & m. wydzielone & 7822 & 14231 & 20218 & 42 \\
\hline 2 & Beijing & m. wydzielone & 5522 & 10301 & 16447 & 59 \\
\hline 4 & Canton & Guangdong & 3510 & 8091 & 10642 & 31 \\
\hline 5 & Shenzhen & Guangdong & 1082 & 6481 & 10359 & 60 \\
\hline 6 & Wuhan & Hubei & 4091 & 6756 & 9291 & 37 \\
\hline 7 & Dongguan & Guangdong & 3792 & 6787 & 7541 & 11 \\
\hline 8 & Foshan & Guangdong & 552 & 3870 & 7271 & 88 \\
\hline 9 & Chengdu & Syczuan & 1867 & 4273 & 6317 & 69 \\
\hline 10 & Chongqing & m. wydzielone & 2519 & 4913 & 6264 & 27 \\
\hline 11 & Nanking & Jiangsu & 2323 & 4042 & 5828 & 44 \\
\hline 12 & Shenyang & Liaoning & 3651 & 4597 & 5718 & 24 \\
\hline 13 & Xi'an & Shaanxi & 2399 & 3870 & 5206 & 34 \\
\hline 14 & Hangzhou & Zhejiang & 1655 & 3241 & 5162 & 59 \\
\hline 15 & Harbin & Heilongjiang & 2691 & 3627 & 4596 & 26 \\
\hline
\end{tabular}

\footnotetext{
${ }^{4}$ Megalopolis to zespół osadniczy, który powstaje przez zrastanie się sąsiednich aglomeracji (regionów miejskich), tworzacy rozległa strefe zurbanizowana o policentrycznym układzie. Zamiennie z megalopolis stosuje się pojęcie korytarza miejskiego,
} 


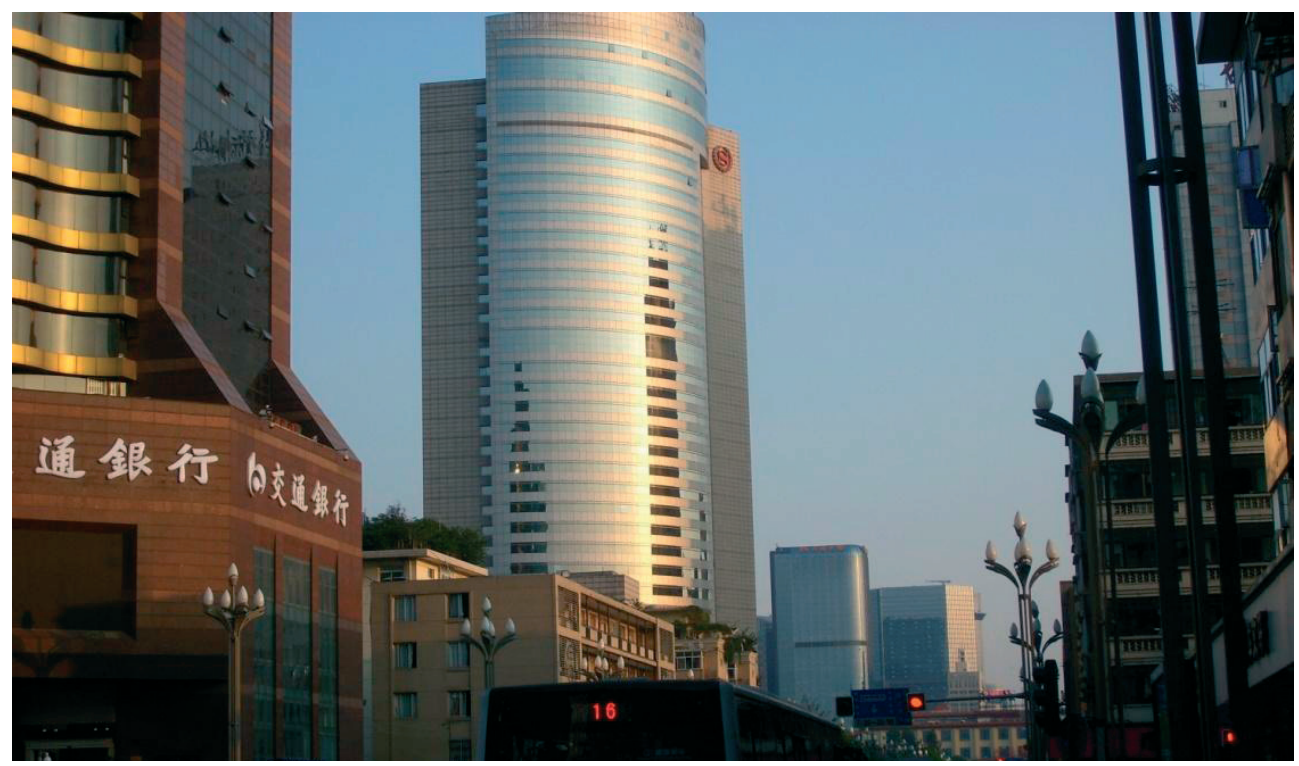

Fot. 4. W centrach miast chińskich szybko powstały wyniosłe wysokościowce, to one są najszybszym odczuwalnym efektem wzrostu gospodarczego- Chengdu(prowincja Syczuan). (Źródło: autor 2013)

\section{Literatura}

1. http://www.geekweek.pl/aktualnosci/23668/chiny-zbuduja-najwieksze-miasto-swiata (dostęp dnia 30.06.2016r).

2. http://wiadomosci.onet.pl/swiat/to-bedzie-najwieksze-miasto-na-swiecie/bc9ef (dostęp dnia 30.06.2016 r).

3. http://www.bryla.pl/bryla/1,85298,15701634,Chinskie_miasta_beda_jeszcze_wieksze_Wladz e_maja.html(dostęp dnia 30.06.2016 r).

4. http://www.chinatales.pl/70-chiny-najwiekszy-plac-budowy naswiecie.html? ckattempt=1 (dostępdnia 30.06.2016 r).

5. Gaweł D. Zielone przestrzenie publiczne czy parki? Wspótczesne tendencje kształtowania terenów rekreacyjnych miast. Współczesne miasto jako środowisko życia człowieka zintegrowane z przyrodą. Wydział Budownictwa i Architektury Politechniki Świętokrzyskiej, Kielce 2015.

6. GawełD. From a megalopolis, to a smart city. Future of the city-cities of the future. Monografia 454. Politechnika Krakowska, Kraków. 2014.

7. Stephen S.Y., Lau Q.Z. Genesis of a Vertical City In Hong Kong. International Journal of HighRise Buildings 4(2) (2015).

8. Janowski M. Totalitarna wolność, nowy krajobraz miejski na przykładzie Zhujiang New Town. Nowoczesność w architekturze. Urbanistyka i architektura miasta postindustrialnego. Wydział Architektury Politechniki Śląskiej, Gliwice 2011 


\title{
Synergy in economics, as an element of urban creation in China
}

\section{Dariusz Gawel}

Independent Laboratory of Architecture, Faculty of Civil Engineering and Architecture, Lublin University of Technology, email: d.gawel@pollub.pl

\begin{abstract}
This article is about spatial and architectural occurrences, taking place in front of our eyes in Middle Kingdom. Impressive pace of development in Asian and global scale imposes capital surplus location in properties. We can observe creation of new housing areas, districts or even Chinese cities in unprecedented scale. With this new architecture and space creation, the question arises as to what is the quality of that built environment in China. At the same time, an exponential economical development, attracts unknown in this country social occurrences like: sudden population migration to cities, one child policy easing and creation of new middle class in society. Country urbanization burgeons very quickly, but government still has a lot of plans to develop. In this article author is trying to analyze spatial and architectural occurrences, which affect society in conditions of quick economical development. In this case, synergy in economics is a contribution to describe what are the conditions in creation of built environment in the cities. China is a country, where people treat tradition, beliefs and family as fundamental values. How to create a housing environment with free market rules in this society? Author is analyzing those occurrences, basing on literature criticism and own observations made "in situ".
\end{abstract}

Keywords: synergy in economics, element of urban creation, city, China. 
